\title{
Analytical study of the physicochemical characteristics from Melipona subnitida D. honey in adequation to Brazilian law
}

\author{
Dayana Calixto BRAGA ${ }^{1 *}$ (D), Maria da Conceição Tavares Cavalcanti LIBERATO¹, Victor Luís Ferreira LIMA, \\ José Amilcar Mendes de ARAÚJO NETO1
}

\begin{abstract}
Honey has different physical and chemical properties because it is produced from the nectar of plants. The present work had the objective of analyzing laboratory tests on honey bee Melipona subnitida D. from Ceará, in comparing them with other honeys from the Northeast Region, making it possible to know better the standards of these honeys, in order to verify their suitability to the Brazilian legislation and contribute to a future more appropriate and specific legislation for the honey of the native bees, since the existing legislation only addresses bee products from Apis mellifera L. Studies were correlated with Fiehe/hydroxymethylfurfural (HMF) in addition to pH/acidity, Lund, lugol, moisture, ash, soluble solids ( ${ }^{\circ}$ Brix) and coloring. For the moisture test there's a 100\% failure rate to the standards established by current Brazilian legislation, 38.46\% in relation to the acid test and $29.03 \%$ for HMF. Inadequacies to the legislation occur due to the different floral origins and edaphoclimatic factors. However, the most relevant factor is the difference between the bees' species Apis mellifera L. and Melipona subnitida D. that originate the honeys, each species conferring specific characteristics to its product.
\end{abstract}

Keywords: bee; quality; specific legislation.

Practical Application: Quality control of honey bees Melipona subnitida D. and its suitability under Brazilian legislation.

\section{Introduction}

According to Brasil (2000) and Baltrušaitytè et al. (2007, p. 502-503), honey is the product of flower nectar bees, secretions of living parts of plants, or excretions of sucking insects that are in plants. Most plants produce nectar, used by bees to produce honey and its bioactive components thus, composition and antioxidant capacity vary from the floral source used to collect nectar as well from external factors such as climate, environment and any processing through which it has passed.

The rational breeding of bees is an activity in which good economic, ecological and social results can be obtained. This activity, developed over time by small and medium producers, has aroused the interest of many Brazilian creators and institutions. In beekeeping, there are two main production lines: Beekeeping and Meliponiculture. Within Beekeeping, knowledge about honey has been studied in several regions of Brazil, but in Meliponiculture, these studies are more recent, being developed with regional bees (Rodrigues et al., 2005).

It is common to find variations between physical and chemical composition of honey, since several factors interfere in its quality. This interaction comes from variables not controlled by man, such as climatic conditions, stage of maturation, bee species and flowering type (Pérez et al., 2007; Campos et al., 2003), as well as the processing and storage of this product (Azeredo et al., 2003).

Honey from Melipona bee is a product that has presented a high market demand, with prices higher than that of Apis bees.
However, it still lacks studies regarding its physico-chemical characteristics, which would help defining quality standards for its commercialization, in comparison to the standards and characteristics established for honey of Apis mellifera L. (Souza et al., 2009). Due to these factors, it is fundamental the characterization of honeys in order to create standards according to the region in which they are located, in order to establish comparative criteria for analysis and control of possible frauds.

Brazilian Ministry of Agriculture, Livestock and Supply, by the $11^{\text {th }}$ Normative Instruction on October $20^{\text {th }}, 2000$ - Technical Regulation on Honey Identity and Quality (Brasil, 2000) governs physicochemical patterns that determine the characterization of bee hives Apis mellifera L., but does not have specifications for honeys from other species of bees. Thus, the present work aimed to characterize the honey bee Melipona subnitida $\mathrm{D}$. from the State of Ceará, comparing them to other studies and legislation about honey, in order to contribute to the definition of identity and quality standards for this kind of honey.

\section{Materials and methods}

The honey samples were obtained by direct and indirect contact with producers from different localities in the cities of Ceará State (Ibicuitinga, Itatira, Acopiara, Morada Nova, Nova Russas, Palmácia, Maranguape, Trairi, Barreira, Paraipaba, Barroquinha, Cascavel, Crateús, Pacajus, Redenção, Capistrano, Baturité and Paramoti), totaling eighteen cities. 
Honeys were collected at different times between the years 2013-2015, depending on the floral origin. The physicochemical analyzes were carried out at the Laboratory of Biochemistry and Biotechnology (LABBIOTEC) and in the Laboratory of Chemistry of Natural Products (LQPN) of the State University of Ceará (UECE), comparing these results to the honeys produced from other states in Northeastern Region, such as Paraíba State and Rio Grande do Norte State, presented in scientific papers of several authors, besides the qualitative analysis of the current legislation, thus contributing to the definition of identity and quality norms for this type of honey.

This study documentary research was executed in 2017, between the months of August and November. It covered the localities that have activities with Melipona subnitida $\mathrm{D}$ in the Brazilian Northeast. Sampling focuses on physicochemical analyzes of Melipona honeys to verify the product quality. Works with relatively incomplete databases whose studies did not have enough knowledge to incorporate quality into this quantitative analysis were excluded from it.

The results were compared to the Brazilian Honey Law of Apis mellifera L. (Brasil, 2000) and the authors Sousa et al. (2016), who studied the honeys from other region of the Brazilian Northeast (Seridó region, Rio Grande do Norte State and the southern region of Paraiba) semi-arid region and also the work of Silva et al. (2013) with honey from Paraíba State.

The methodology refers to the performance of the analyzes of Fiehe, pH, Lund, lugol, moisture, ash, soluble solids and coloring for the characterization of this product. In addition to the obtained data analysis, those honey studies were compared, aiming to better understand the physicochemical characteristics of the honey and bee species under study.

\subsection{Description of the methodologies of the chemical analyzes}

Reaction of Fiehe

The Fiehe test is a qualitative reaction to detect the presence of HMF (Hydroxymethylfurfural) in honey (Instituto Adolfo Lutz, 2005). The colorimetric reaction occurs between the Resorcin and HMF compounds. This experiment aims to determine the presence of substances produced in the overheating or addition of sugar syrups in honey. If the honey is overheated or has been tampered with by commercial glucose, the appearance of an intense red color will occur.

\section{pH}

The concentration of $\mathrm{H}^{+}$ions is measured with the aid of a $\mathrm{pH}$ meter, after its calibration. In the Brazilian Legislation, there is no determination of $\mathrm{pH}$ analysis as mandatory for honey quality, and can be performed as an aid to total acidity (Araújo et al., 2006). The maximum accepted acidity is $50 \mathrm{mEq} / \mathrm{kg}$ of honey (Brasil, 2000).

\section{Lund reaction}

It is based on the precipitation of natural honey proteins by Tannic Acid, which allows the identification of the presence of albuminoids (Instituto Adolfo Lutz, 2005). In the presence of pure honey a solid deposit is formed in the range of 0.6 to $3.0 \mathrm{~mL}$ In the presence of adulterated honey, there will be no deposit formation or it will be negligible. A deposit above $3.0 \mathrm{~mL}$ will indicate that this honey is a poor quality product.

\section{Lugol reaction}

It is a colorimetric reaction with addition of drops of Lugol's solution (Instituto Adolfo Lutz, 2005). If the honey has the presence of commercial glucose, the color of the solution will turn reddish brown to blue. The color will have intensity depending on the quality and quantity of dextrins in commercial glucose or starch (Mendes et al., 2009).

\section{Moisture testing}

The method used is the Refractometer Chataway, indirect method that determines the index of refraction of honey at $20{ }^{\circ} \mathrm{C}$, whereby through the reference table is converted the value obtained for percentage of moisture. Brazilian legislation determines that the value of moisture may not be below $16.8 \%$ and not more than 20\% for Apis honeys (Brasil, 2000).

\section{Ash content}

The ash content is based on the total oxidation of the organic matter of $20 \mathrm{~g}$ of honey, obtaining a fixed mineral residue by incinerating the samples in muffle at $550^{\circ} \mathrm{C}$ until constant weight Association of Official Analytical Chemists (1990).

Calculation of ash content:

$$
\begin{array}{r}
\% \text { ash }=\text { crucible mass with sample calcined }- \\
\text { crucible mass without sample X } 100
\end{array}
$$

According to Ojeda de Rodríguez et al. (2004) honey normally has a low ash content this value will depend on the material that the bees collected during nectar gathering.

\section{Soluble solids ( ${ }^{\circ}$ Brix $)$}

Soluble solids contents are determined directly through a refractometer and the result is expressed as ${ }^{\circ} \mathrm{Brix}$ representing $\%(\mathrm{w} / \mathrm{w})$ of soluble sucrose present in a solution at $20^{\circ} \mathrm{C}$.

\section{Coloring test}

It is determined by using the photoelectric colorimeter with a wavelength of $635 \mathrm{~mm}$, in a $1 \mathrm{~cm}$ cell. The color is expressed in $\mathrm{mm}$ by the Pfund scale and calculated by the following formula: Color $=(371.39 \times$ Abs635) $-38.70($ Bianchi, 1981).

\section{Results and discussion}

These honey physicochemical analyzes were aimed at increasing the knowledge on physicochemical characteristics of Melipona subnitida D. honey from the Northeastern states of Brazil, in 
comparison to the ones from Ceará, Seridó, at the state of Rio Grande do Norte, of the rugged region of Paraíba and Paraíba.

In Ceará depending on the prevailing climate it rains at certain times of the year. In the Tropical hot semiarid climate, rain from January to April in the cities Ibicuitinga and Itatira, February to April in Acopiara, Morada Nova and Nova Russa. Tropical hot and humid, from January to May in Palmácia and Maranguape; Tropical warm semi-arid mild, January to April in Trairi, from February to April in Barreira, from January to May, Paraipaba, February to May in Barroquinha and Cascavel; Tropical warm semi-arid mild and warm semi-arid, rains from January to April, Crateús; Tropical warm semi-arid mild, warm sub-humid, January to April, Pacajus; Tropical warm semi-arid mild, warm sub-humid and warm humid, from January to April in Redenção, February to April, Capistrano; Tropical warm semi-arid, warm sub-humid and warm humid, rains from January to May, Baturité; Tropical warm semi-arid, warm semi-arid mild and warm sub-humid, rain February to April in Paramoti. The honeys from the state of Ceará have different scale of semiarid climate. For each city there is a description of the climate type and rainy season. This makes the difference between the honeys as it implies different blossoming (Leal, 2019).
In order to verify the quality of the obtained honeys, the following analyzes were carried out: Fiehe reaction, $\mathrm{pH}$, Lund reaction, Lugol reaction, Moisture test, Ash, Soluble solids and Coloring test and the results were on Table 1.

Fiehe test can indicate whether the honey has been adulterated, added sugar, overheated or extended storage time. Half of the samples from the Ceará honeys are in agreement with Braga's (2014) work, being positive to the Fiehe test, possibly due to the climatic conditions, since the honeys from tropical countries, warmer regions, may have high content of HMF without the honey having undergone adulteration or overheating. In the honeys arranged in Tables 2 and 3 also referring to the Northeast region are not positive in this parameter.

In Melipona subnitida D. honeys from the Ceará State, $\mathrm{pH}$ values varied from 2.56 to 3.94 , however there are no specifications regarding to $\mathrm{pH}$ in the legislation (Brasil, 2000). Compared to the honeys of Sousa et al. (2016) ranging from 3.1 to 5.3 , and the honeys analyzed by Silva et al. (2013) there were variation from 2.90 to 3.83 , coming close to the values found for honey from Ceará.

The work of Alves et al. (2011) states that the acidity of stingless honey is usually very high in relation to Apis mellifera

Table 1. Physical-Chemical Characterization of Melipona subnitida D. honeys from Ceará.

\begin{tabular}{|c|c|c|c|c|c|}
\hline Tests & Mean & Standard deviation & $\begin{array}{c}\text { Minimal and } \\
\text { maximum values }\end{array}$ & Variation coefficient & Standard/law ${ }^{\star}$ \\
\hline Fiehe & Negative/Positive & - & - & - & Negative (Max. $60^{*}$ ) \\
\hline $\mathrm{pH}$ & 3.32 & 0.36 & $2.56-3.94$ & 10.84 & - \\
\hline Lugol & Negative & - & - & - & Negative \\
\hline Moisture (\%) & $>20 \%$ & - & - & - & Between 16.8 and $20 \%^{*}$ \\
\hline Ashes $(\% \mathrm{p} / \mathrm{p})$ & 0.39 & 0.25 & $0.03-0.61$ & 64.10 & $\operatorname{Max} 0.6 \%^{*}$ \\
\hline
\end{tabular}

${ }^{\star}$ Brasil (2000).

Table 2. Physical and chemical characterization of the Melipona subnitida D. honey from the region of the Seridó region - Rio Grande do Norte State and the wild Paraíba State.

\begin{tabular}{|c|c|c|c|c|c|}
\hline Tests & Mean & Standard deviation & $\begin{array}{c}\text { Minimal and } \\
\text { maximum values }\end{array}$ & Variation coefficient & Standard/law ${ }^{*}$ \\
\hline Fiehe & Negative & - & - & - & Negative (Max.60*) \\
\hline $\mathrm{Ph}$ & 3.95 & 0.95 & $3.1-5.3$ & 24.05 & - \\
\hline Acidity & 42.65 & 30.55 & $17.8-86.8$ & 71.62 & $\max .50$ meq.kg-1* \\
\hline Moisture (\%) & 26.4 & 2.14 & $23.90-28.9$ & 8.30 & Between 16.8 and $20 \% *$ \\
\hline Ashes $(\% \mathrm{p} / \mathrm{p})$ & 0.20 & 0.22 & $0.04-0.52$ & 110 & Max. $0,6 \%^{*}$ \\
\hline Brix (\%) & 72.55 & 1.53 & $71.1-74.7$ & 1.86 & - \\
\hline Coloring & Amber & - & - & - & - \\
\hline
\end{tabular}

*Brasil (2000). Source: Sousa et al. (2016).

Table 3. Physical-Chemical Characterization of Melipona subnitida D. honey of the Paraíba.

\begin{tabular}{|c|c|c|c|c|c|}
\hline Tests & Mean & Standard deviation & $\begin{array}{c}\text { Minimal and } \\
\text { maximum values }\end{array}$ & Variation coefficient & Standard/law ${ }^{\star}$ \\
\hline Fiehe & 13.42 & 1.64 & $10.80-15.76$ & 12.19 & Negative (Max. 60*) \\
\hline $\mathrm{pH}$ & 3.34 & 0.28 & $2.90-3.83$ & 8.47 & - \\
\hline Acidity & 39.65 & 14.89 & $24.66-59.66$ & 37.54 & Max. 50 meq. $\mathrm{kg}^{-1 \star}$ \\
\hline Moisture (\%) & 23.17 & 0.66 & $22.20-24.40$ & 2.85 & Between 16.8 and $20 \% *$ \\
\hline Ashes $(\% \mathrm{p} / \mathrm{p})$ & 0.07 & 0.05 & $0.03-0.20$ & 71.43 & Max. $0.6 \%{ }^{*}$ \\
\hline
\end{tabular}

${ }^{\star}$ Brasil (2000). Source: Silva et al. (2013). 
honey, being a notable characteristic of the flavor, being related to the state of maturation of honey. The acidity of honey is a factor determined by the species of bee and flowering, justifying the regional analysis, and the bee species that produces it, in order to standardize the parameters of this product.

The average acidity content found in the honeys of the Northeast region, analyzed by Sousa et al. (2016) was 42.65 , being only a non-standard sample, while in the Paraíba honey the acid content was 39.65 , being also below the value of 50 meq. $\mathrm{kg}^{-1}$ stipulated in the Legislation (Brasil, 2000), but four analyzes of the nine performed by this author exceeded this limit.

For the Lund test, in the Ceará honeys, despite having a high coefficient of variation of 40.9 , the values of maximum 2.0 and minimum of 0.5 , where only the value of 0.5 is out of the limit between 0.6 and $3.0 \mathrm{~mL}$, parameter indicating a quality honey (Instituto Adolfo Lutz, 2005). In the qualitative test of Lugol (which indicates the presence of commercial glucose) all the results were negative, which certifies that the Melipona subnitida honeys from Ceará State are pure honeys and have not undergone adulteration process.

The moisture test is the most distinguishable analysis from the standards governed by the current legislation. All the honey of Melipoma subnitida analyzed in this work presented a value of moisture above $20 \%$. The honeys of this bee species, because they have high moisture values, are suitable for fermentation, and strict hygiene standards are necessary during collection and adequate packaging. Moisture is one of the parameters that several authors suggest as the greatest difference between Apis mellifera and Melipona subnitida honey. Other types of analyzes require more in-depth studies, as there is little information available in the literature (Carvalho et al., 2005).
Although all the tables have presented very different values of Ash, with a high coefficient of variation, only the honey from Itatira (Ceará State) presented the ash value of $0.61 \%$ discordant to the allowed one, being a little elevated when compared to the Current Legislation for honeys of Apis mellifera, whose maximum allowed is $0.6 \%$ (Brasil, 2000). The ash content is related to the minerals present in the honey and with its botanical and geographical origin, being a parameter used to ascertain its quality, since it can determine some irregularities, such as lack of hygiene and no decantation and/or filtration in the honey-packing process by the beekeeper or producer of Melipona subnitida D., also influencing its coloration, because in darker honeys there is the presence of a higher concentration of these minerals (Gois et al., 2013; Mendes et al., 2009).

Soluble solids values varied from $61 \%$ to $81 \%{ }^{\circ}$ Brix, being in an average of 70.82 , slightly above the values found by Sousa et al. (2016), where their results ranged from $71.1 \%$ to $74.7 \%$.

Table 4 presents the Coloring test. Samples of the Melipona subnitida D. (Jandaíra bee) honeys come from six cities in the hinterland of Ceará State. The observed colors vary in the range of $1.03 \mathrm{~mm}$ to $283.88 \mathrm{~mm}$ relative to the colors white-water and dark amber, respectively. The other samples were between light and dark amber staining. In Sousa et al. (2016) the values ranged from 35.8 to 103.4 , indicating the amber color. Analyzes shown that the colorations presented are within the parameters established in the Legislation concerning pure honey, and can vary from white-water to dark amber (Brasil, 2000). This shows that Melipona subnitida D. honeys from Ceará State follow the same pattern.

After analyzing the means of the three states in Table 5, we observed that some patterns (moisture, acidity, HMF) are more divergent when compared to the standards of the legislation

Table 4. Coloring of samples of Melipona subnitida D. honeys from Ceará State.

\begin{tabular}{lccc}
\hline \multicolumn{1}{c}{ Sampling Site } & Absorbance Mean $635 \pm$ Deviation & Result in $\mathrm{mm}_{\text {fund }}$ & Classification \\
\hline Morada Nova & $0.565 \pm 0.040$ & 171.10 & Dark amber \\
Limoeiro do Norte & $0.508 \pm 0.007$ & 283.88 & Dark amber \\
Ibicuitinga & $0.311 \pm 0.003$ & 84.60 & Light amber \\
Aracati & $0.196 \pm 0.002$ & 34.09 & Extra-light amber \\
Itatira & $0.548 \pm 0.028$ & 164.8 & Dark amber \\
Itapiúna & $0.107 \pm 0.003$ & 1.03 & Water-white \\
\hline
\end{tabular}

Table 5. Comparison of the averages of the Northeast Region with the Brazilian Legislation (Brasil, 2000)*, compared to the averages proposed by Villas-Bôas \& Malaspina (2005)** and the standards proposed in this study.

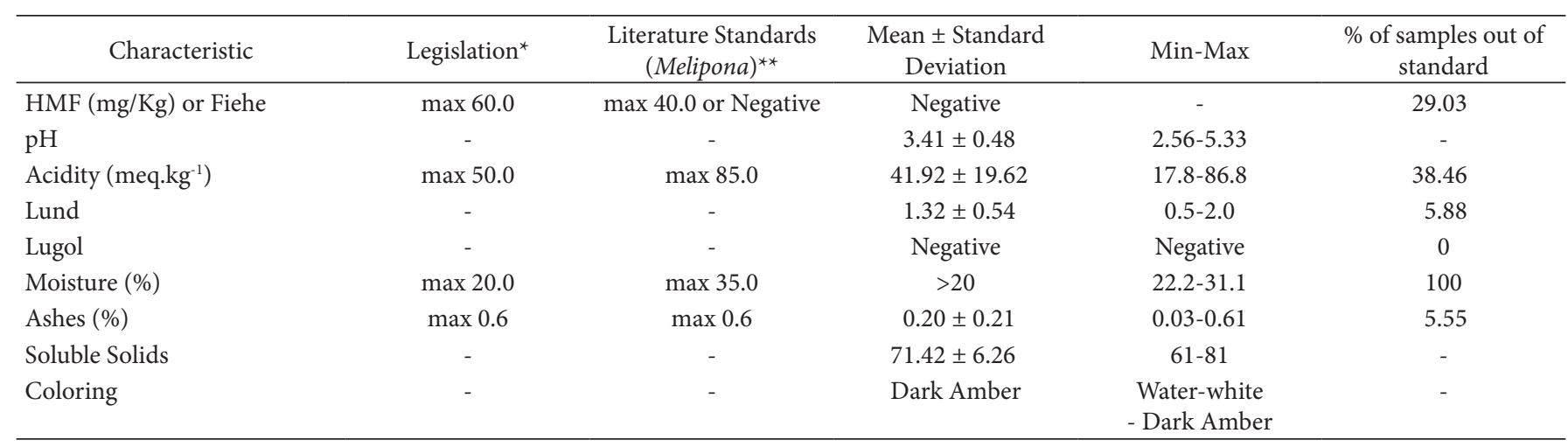

${ }^{\star}$ Brasil (2000); ${ }^{* *}$ Villas-Bôas \& Malaspina (2005). 
and when confronted with the data of Villas-Bôas \& Malaspina (2005) are more similar. We evaluated other physicochemical characterizations that are not found in the legislation, but are fundamental to guarantee the quality of this bee product, such as: pH, Lund, Lugol, soluble solids.

\section{Conclusions}

It is of great importance the study of the honey characterization of native stingless bees, Melipona subnitida D., in order to create edaphoclimatic and floristic patterns of the regions, due to their peculiar physicochemical characteristics and little known, since it has a different chemical composition.

Melipona subnitida D. honeys from Ceará State were analyzed, comparing them with other authors with honeys from the Northeast Region. A similarity was observed in the vicinity of the standards means, however when checking their adequacy to the Brazilian Legislation (Brasil, 2000), some parameters such as HMF, moisture and acidity are divergent due to the bee's honey characteristics. The lack of adequacy occurs due to the existing legislation being tied only to Apis mellifera honey, and further studies are needed to assist in the inclusion or adequate legislation of the bee honeys Melipona subnitida D. (Jandaíra).

It is certain that specific legislation would facilitate the action of the Sanitary Surveillance in the verification of good practices in the processing and storage of the product, in the regulation of this type of products with the seal of the Federal Inspection Service (SIF), department that inspects products of animal origin, procedures that would inhibit possible fraud.

\section{References}

Alves, T. T. L., Meneses, A. R. V., Silva, J. N., Parente, G. D. L., \& Holanda Neto, J. P. (2011). Caracterização físico-química e avaliação microbiológica de méis de abelhas nativas do Nordeste Brasileiro. Revista Verde, 6(3), 91-97. Retrieved from https://www.gvaa.com. br/revista/index.php/RVADS/article/view/735

Araújo, D. R., Silva, R. H. D., \& Sousa, J. S. (2006). Avaliação da qualidade físico-química do mel comercializado na cidade de Crato, CE. Revista de Biologia e Ciências da Terra, 6(1), 51-55. Retrieved from https:// www.redalyc.org/pdf/500/50060108.pdf

Association of Official Analytical Chemists - AOAC. (1990). Official methods of analysis of the Association of Official Analytical Chemists (2nd ed.). Washington: AOAC.

Azeredo, L. C., Azeredo, M. A. A., Souza, S. R., \& Dutra, V. M. L. (2003). Protein contents and physicochemical properties in Money simples of Apis mellifera of different origins. Food Chemistry, 80(2), 249-254. http://dx.doi.org/10.1016/S0308-8146(02)00261-3.

Baltrušaitytè, V., Venskutonis, P. R., \& Čeksteryte, V. (2007). Radical scavenging activity of different floral origin honey and beebread phenolic extracts. Food Chemistry, 101(2), 502-514. http://dx.doi. org/10.1016/j.foodchem.2006.02.007.

Bianchi, E. M. (1981). La miel, características y composición: análisis y adulteraciones. Santiago del Estero: UNSE-CEDIA.

Braga, D. C. (2014). Análise das propriedades físico-químicas dos méis das abelhas Apis mellifera L. e Melipona subnitida D. de diferentes locais do nordeste brasileiro (Trabalho de conclusão de curso). Universidade Estatual do Ceará, Fortaleza.

Brasil, Ministério da Agricultura Pecuária e Abastecimento. (2000, October 23). Regulamento técnico de identidade e qualidade do mel (Instrução normativa no 11 , de 20 de outubro de 2000). Diário Oficial [da] República Federativa do Brasil.

Campos, G., Della-Modesta, R. C., Silva, T. J. P., Baptista, K. E., Gomides, M. F., \& Godoy, R. L. (2003). Classificação do mel em floral ou mel de melato. Food Science and Technology, 23(1), 1-5. http://dx.doi. org/10.1590/S0101-20612003000100002.

Carvalho, C. A. L., Souza, B. A., Sodré, G. S., Marchini, L. C., \& Alves, R. M. O. (2005). Mel de abelhas sem ferrão: contribuição para a caracterização físico-química. Cruz das Almas: Nova Civilização.

Gois, G. C., Lima, C. A. B., Silva, L. T., \& Rodrigues, A. E. (2013). Composição do mel de Apis mellifera: requisitos de qualidade. Acta Veterinaria Brasilica, 7(2), 137-147. http://dx.doi.org/10.21708/ avb.2013.7.2.3009.

Instituto Adolfo Lutz - IAL. (2005). Métodos químicos e físicos para análise de alimentos (3. ed.). São Paulo: IAL.

Leal, J. (2019). Anuário do Ceará: 2019-2020. Fortaleza: Fundação Demócrito Rocha.

Mendes, C. G., Silva, J. B. A., Mesquita, L. X., \& Maracajá, P. B. (2009). As análises de mel: revisão. Revista Caatinga, 22(2), 7-14. Retrieved from https://periodicos.ufersa.edu.br/index.php/caatinga/article/ view/789

Ojeda de Rodríguez, G., Sulbarán de Ferrer, B., Ferrer, A., \& Rodríguez, B. (2004). Characterization of honey produced in Venezuela. Food Chemistry, 84(4), 499-502. http://dx.doi.org/10.1016/S03088146(02)00517-4.

Pérez, R. A., Iglesias, M. T., Pueyo, E., González, M., \& Lorenzo, C. (2007). Amino acid composition and antioxidant capacity of Spanish honeys. Journal of Agricultural and Food Chemistry, 55(2), 360-365. http://dx.doi.org/10.1021/jf062055b. PMid:17227066.

Rodrigues, A. E., Silva, E. M. S., Beserra, E. M. F., \& Rodrigues, M. L. (2005). Análise físico-química de méis das abelhas Apis mellifera e Melipona scutellaris produzido em duas regiões do estado da Paraíba. Ciência Rural, 35(5), 1166-1171. http://dx.doi.org/10.1590/ S0103-84782005000500028.

Silva, T. M. S., Santos, F. P., Rodrigues, A. E., Silva, E. M. S., Silva, G. S., Novaes, J. S., Santos, F. A. R., \& Camara, C. A. (2013). Phenolic compounds, melissopalynological, physicochemical analysis and antioxidant activity of jandaíra (Melipona subnitida) honey. Journal of Food Composition and Analysis, 29(1), 10-18. http://dx.doi. org/10.1016/j.jfca.2012.08.010.

Souza, B. A., Marchini, L. C., Oda-Souza, M., Carvalho, C. A. L., \& Alves, R. M. O. (2009). Caracterização do mel produzido por espécies de Melipona Illiger, 1806 (apidae: meliponini) da região nordeste do Brasil: 1. Características físico-químicas. Química Nova, 32(2), 303-308. http://dx.doi.org/10.1590/S0100-40422009000200007.

Sousa, J. M. B., Souza, E. L., Marques, G., Benassi, M. T., Gullón, B., Pintado, M. M., \& Magnani, M. (2016). Sugar profile, physicochemical and sensory aspects of monofloral honeys produced by different stingless bee species in Brazilian semi-arid region. Food Science and Technology, 65, 645-651. http://dx.doi.org/10.1016/j.lwt.2015.08.058.

Villas-Bôas, J. K., \& Malaspina, O. (2005). Parâmetros físico-químicos propostos para o controle de qualidade do mel de abelhas indígenas sem ferrão no Brasil. Mensagem Doce, 82, 6-16. Retrieved from https://www.apacame.org.br/mensagemdoce/82/artigo2.htm 